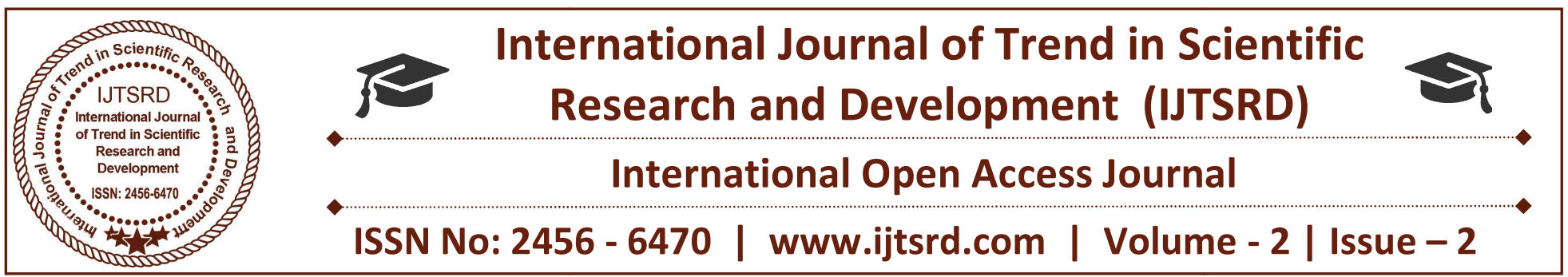

\title{
Clinical Applications of Metabolomics in Diabetes Research
}

\author{
Seema Ahad \\ Udaipur, Rajasthan, India
}

\section{ABSTRACT}

Diabetes mellitus is a multi-factorial disorder related to a dysregulated metabolism. a holistic technique emphasizing each of the person factors with regards to finish pathophysiology of the disease is vital to our information of this heterogeneous disorder. numerous technical advances inside the area of purposeful genomics which include metabolomics and proteomics useful resource in comprehending the nation of the overall organic machine and for this reason can be applied to decipher the complicated interactions among additives of the metabolic machine in human diabetes. above-referred to strategies combined with a fixed of bioinformatics equipment and available databases goal to profile big selection of proteins and metabolites repertoire in humans. the accurate and comprehensive measurements of those molecules is hired to analyze complicated interactions of metabolites and proteins now not simplest amongst themselves but additionally with genes, transcripts and other small molecules to decipher cell microenvironment and the results due to drug intervention. this assessment gives an overview of the applications of metabolomics in human diabetes studies. we additionally talk the ability of combining exceptional bioinformatics tools with the omics technique to improve the medical expertise closer to discovery of biomarkers to monitor and adjust general human fitness with appreciate to the deregulated metabolic state, a function of diabetes mellitus.

\section{INTRODUCTION}

Type 2 diabetes (T2D) and its co morbidities have reached epidemic proportions [1], with extra than half one thousand million instances expected by means of 2030 [2]. Glycated hemoglobin (hbalc), on the other hand, provides statistics on glucose control in the course of the months preceding the preliminary testing. in spite of those systematic measures, up to 60 percent of T2D cases are in no way recognized [3]. Early prognosis of T2D is extraordinarily crucial, as early interventions would possibly put off or even prevent complete-blown sickness [5-8]. T2D is hardly ever a static circumstance, however rather one that evolves and adjustments over the years throughout the lifespan of the character. Additionally, not all individuals are affected similarly through the ailment [9-11]. Indeed, scientific risk factors appear to cluster in sure individuals greater than others and are frequently independent of body mass index (BMI) $[12,13]$. Giant variation is also obvious within the reaction of people to remedy in addition to their susceptibility to diabetes-associated headaches [14]. This variability both in ailment development and remedy reaction emphasizes the need for added tools for predicting ailment progression and treatment achievement. This review examines metabolomics as a singular technique in accomplishing these desires. metabolomics is a reasonably new method for studying metabolic modifications linked to disease improvement and progression and for locating predictive biomarkers to enable early interventions, which might be most effective in opposition to T2D and its co morbidities. in metabolomics, the abundance of a comprehensive set of small biomolecules (metabolites) is measured, accordingly giving insight into disease-related metabolic alterations. This assessment shall deliver an outline of simple metabolomics methods and will highlight current metabolomics studies successes in the prediction and analysis of T2D. we summarized key metabolites converting in reaction to T2D. despite massive variations in predictive biomarkers, many studies have replicated increased plasma tiers of 
branched-chain amino acids and their derivatives, aromatic amino acids and $\alpha$-hydroxybutyrate in advance of T2D manifestation. in assessment, glycine tiers and lysophosphatidylcholine c18:2 are depressed in both predictive studies and with overt sickness. the use of metabolomics for predicting T2D co morbidities is gaining momentum, as are our tactics for translating primary metabolomics studies into clinical programs. As an end result, metabolomics has the ability to enable knowledgeable selection-making in the realm of personalized medicinal drug.

in foremost, metabolomics can provide positive advantages relative to different "omics" technologies (genomics, transcriptomics, proteomics) in diabetes research: 1) estimates vary, but one modern-day source, the human metabolome database (hmdb)canada (three), currently lists $\sim 6,500$ discrete small molecule metabolites, extensively less than the estimate of 25,000 genes, a hundred,000 transcripts, and 1,000,000 proteins. 2) metabolomics measures chemical phenotypes which are the internet result of genomic, transcriptomic, and proteomic variability, therefore presenting the most integrated profile of organic popularity. three) metabolomics is in idea a precise tool for discerning mechanisms of movement and viable toxicological effects of drug cures. but, metabolomics remains a subject in its infancy, with full-size boundaries and potential for misuse of technology and over interpretation of statistics. Here we are looking for to offer an essential evaluation of development so far in application of metabolomics technology for the know-how of diabetes and obesity mechanisms, for sub classification of different forms of diabetes to help in tailoring of healing strategies, and for greater certain evaluation of the safety and efficacy of medication used to treat the sickness.

\section{Metabolomics}

Metabolomics is the complete characterization of metabolites in biological structures. The term metabolomics is much like that of older technology which includes genomics (dealing with genes), transcriptomics(managing gene transcripts), and proteomics (managing proteins). The metabolome is made out of small intermediary molecules and products of metabolism, along with the ones associated with strength garage and usage, precursors to proteins and carbohydrates, regulators of gene expression, and signaling molecules. Accordingly, the metabolome as everything of metabolites represents a real-time functional portrait of the cellular or the organism. The metabolome is stimulated with the aid of a plethora of things, which includes weight loss plan, way of life, medicines, gender, and age. In this regard, metabolomics will become a very effective tool as it views the effects of pathological elements from massively distinctive origins in an unmarried size.

precise methods employed inside the observe of metabolomics encompass nuclear magnetic resonance (NMR) [15], gasoline chromatography mass spectrometry (GC-MS) [16], liquid chromatography mass spectrometry (LC-MS) [16], capillaryelectrophoresis mass spectrometry (CE-MS) [17], and high performance liquid chromatography (hplc) [18]. NMR measures differences in the magnetic homes of atomic nuclei, mass spectrometry measures variations in the mass and electric price of the metabolites, and chromatography distinguishes metabolites by using differences in adhesion properties. Even as hyphenated ms methods have the advantages of excessive sensitivity, small pattern volumes, and comparatively low prices, NMR has an extra variety of concurrently detectable molecular species, in addition to easy pattern education and awesome reproducibility.

In all platforms, two basically specific tactics may be selected: targeted profiling or metabolic fingerprinting. For focused profiling, quantitative values for a preselected subset of metabolites are calculated. For accurate results, inner standards must be used to calibrate sample concentrations via including reference materials of recognized concentrations. In mass spectrometry, as an example, a solid isotope-categorized version of the metabolite of hobby is spiked into the pattern. For NMR, an unmarried attention reference substance is delivered; however received values may additionally want to be scaled with the aid of metabolite-specific man or woman calibration elements $[19,20]$.

Samples most usually analyzed thru metabolomics encompass plasma, serum [21], and urine [22, 23], while other pattern sorts which includes cerebrospinal fluid [24] and saliva [25] are used much less often. Metabolomics research may analyze tissue extracts [26]; whole tissue via magic angle spinning (mass) NMR [27] and even residing organisms can be analyzed by using in vivo NMR [28]. Moreover, cell subculture samples and supernatants may be analyzed [29]. 
At gift, there are no generally used, standardized protocols for pattern series and storage for metabolomics studies, a reality that may make a contribution to extra version in metabolomic profiles. for instance, some research acquire samples handiest from fasting contributors, at the same time as other research do not have this as a prerequisite. massive attention differences among the metabolites of plasma and serum organized from the same blood pattern were observed [30]. despite the fact that attention differences were found, plasma and serum metabolites correlate properly with every other, indicating that each sample types permit accurate metabolomics measurements so long as serum and plasma samples are not compared to every other. while plasma showed better over-time stability, serum allowed the quantification of more metabolites because of higher concentrations of decided on metabolites [30]. garage conditions are a critical element for metabolomics studies, in particular for potential research, where samples can be analyzed many years after being accrued. studies discovered no differences among plasma that became frozen right now versus plasma that become saved at four for eight [31] and 24 [32] hours earlier than freezing, respectively. likewise, no great variations in metabolite profiles were found while comparing storage at $-20^{\circ} \mathrm{c}$ and - eighty $^{\circ} \mathrm{c}$ [33]. plasma samples saved at - eighty $^{\circ} \mathrm{c}$ for thirteen to 17 years showed no affect of storage time at the metabolic profile [31]. all these studies suggest that the choice of sample type (serum or plasma) and the storage situations can be a minor problem for metabolomics research.

\subsection{Metabolomics technologies}

mass spectrometry (ms) has been successfully hired to analyze extraordinary procedures relevant to diabetes, which include non-enzymatic protein glycation wherein different hexose sugars would regulate the proteins main to their altered or dwindled features [49] or to obtain metabolic profiles in T2D patients [32,50-53] and for diabetes hazard assessment [18]. because of sensitivity and various chemical identity capabilities, $\mathrm{ms}$ is the tool of choice for obtaining wide metabolic profiles at the side of fuel or liquid chromatography [54,55].

\subsubsection{GAS CHROMATOGRAPHY-MASS SPECTROSCOPY (GC-MS)}

GC-MS is the oldest and a robust tool for qualitative metabolic profiling. GC-MS presents excessive chromatographic decision and lets in for non-focused profiling for the invention of novel metabolites and metabolic pathways [56,57]. GC-MS includes electron effect ionization in which the GC column eluants are delivered into the supply, ionized and fragmented to generate a function fragmentation sample and mass spectrum this is typically used for chemical identification. GC-MS has been drastically used as a discovery tool in steroid characterizations for scientific purposes [56,58,59].

GC-MS has been used for the study of pathways of oxidative stress activated in diabetic macro vascular sickness, both in primate and rodent fashions [60-62]. these studies emphasize the function of oxidized amino acids as capability markers for the assessment of oxidative harm. the chromatographic decision capability of the traditional GC has been further greater by using a more recent approach referred to as complete $\mathrm{GC} \times \mathrm{GC}-\mathrm{MS}$ that has been carried out effectively in metabolomics [63,64]. this technique uses an additional column for 2 dimensional separations that appreciably will increase the analytical overall performance by way of improving the chromatography thereby expanding metabolome coverage $[65,66]$.

\subsubsection{LIQUID CHROMATOGRAPHY-MASS SPECTROMETRY (LC-MS)}

LC-MS involves interfacing of liquid chromatography systems with mass spectrometers. lc gives metabolite separation with the aid of equilibration between a cellular liquid phase and a desk bound stable (or liquid) segment. the coupling of liquid structures to mass spectrometry is facilitated by means of the use of electro spray as the commonly applied ionization technique. software of LC-MS as a reliable generation has accelerated throughout the previous decade [18,67-69]. LC-MS metabolic profiling of 20 nonobese and overweight people confirmed a robust correlation among fasting concentrations of branchedchain and fragrant amino acids and serum insulin [70]. a sturdy correlation has additionally been stated among branched-chain amino acid (bcaa) catabolism and insulin resistance [71]. LC-MS changed into used to generate metabolic profiles from 2,422 normoglycemic individuals accompanied over duration of twelve years of which 201 in the end developed diabetes [18]. this observe suggested a panel of greater than 60 metabolites including branched-chain and aromatic amino acids as predictors of improvement of diabetes over the usual risk elements 
consisting of fasting glucose, body mass index (BMI) and so on.

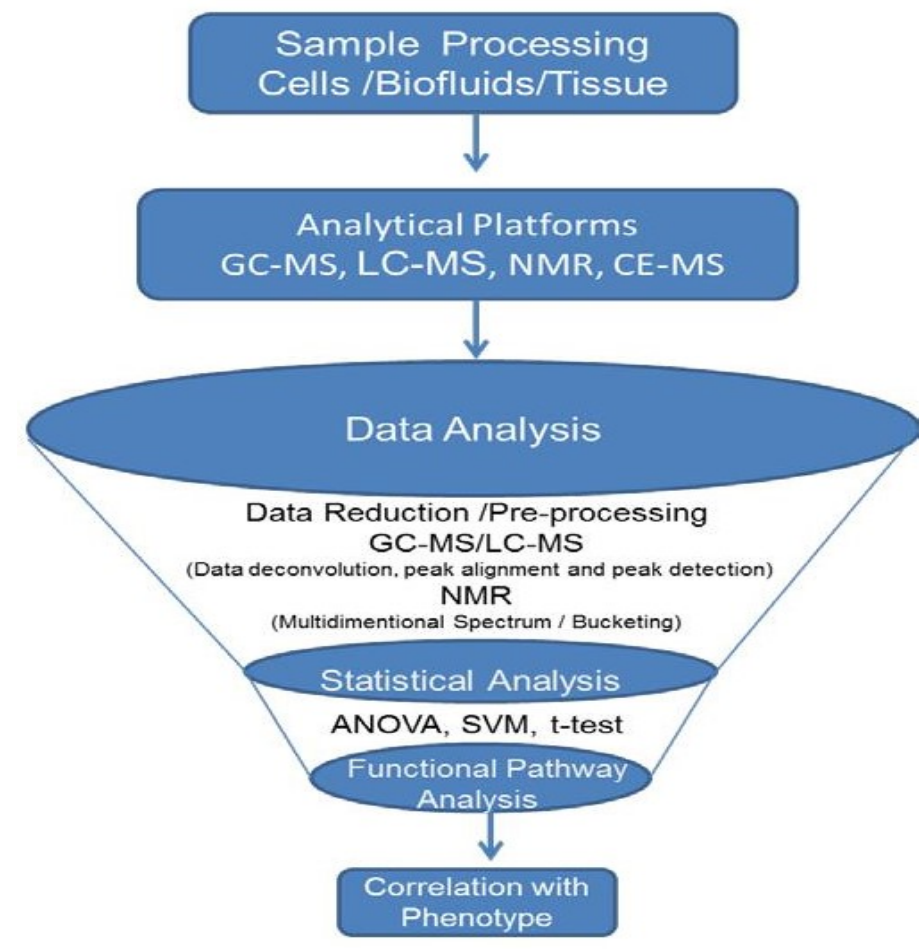

Figure-1.

\subsubsection{CAPILLARY ELECTROPHORESIS- MASS SPECTROMETRY (CE-MS)}

capillary electrophoresis- mass spectrometry (CE-MS) is but some other analytical tool applied for metabolite separation and detection. metabolites are first separated by using ce based totally on price and size, after which selectively detected the use of $\mathrm{ms}$ with the aid of monitoring a huge range of $\mathrm{m} / \mathrm{z}$ values. ce is particularly proper for the separation of polar and charged compounds and can offer complementary facts to lc-ms at the biological composition of sample [72]. it's been effectively used in one-of-a-kind research to detect and quantitative cationic and anionic metabolites now not best across exceptional species but also throughout unique pattern kinds as bio-fluids, cells and tissues [73-78]. Cross-platform analysis making use of CE-MS fingerprinting augmented the identification of metabolites galactosylhydroxylysine, 1-carnitine, amongst others which markedly elevated in urine from diabetic rats in comparison to govern animals [79].

\subsubsection{NUCLEAR MAGNETIC RESONANCE SPECTROSCOPY (NMR}

NMR spectroscopy is a quantitative, quite reproducible and non-selective analytical approach for metabolic profiling [80]. it is impartial of the hydrophobicity or pka of the compounds being analyzed. it has been substantially used for metabolic profiling for greater than twenty years. this technique interrogates all of the molecules gift inside the sample simultaneously by way of using the lively NMR of hydrogen (1h) or carbon (13c)-the so known as commonplace magnetic nuclei [81]. the qualitative issue of NMR lies in its inherent insensitivity and is for this reason suitable best for detection and quantification of metabolites present in tremendously excessive awareness [12]. opportunity techniques are being presently evolved to increase the sensitivity of NMR together with the usage of cryoprobes in enhancing signal to noise for $13 \mathrm{c}$ NMR primarily based metabolomics [82-84]. some other place of development is using hyperpolarized substrates to selectively decorate the resonance of key metabolites

\section{Prognosis: T2D Complications}

aside from diagnosing or predicting the onset of $\mathrm{pd}$ or T2D, every other vital area for metabolomics research is prognosis, eluding disease route and outcome after its onset. the path and final results of pd and T2D are to a huge proportion pushed by way of common complications $\mathrm{C}$ which include cardiomyopathy, nephropathy, peripheral neuropathy, and retinopathy. unluckily, on this area, little metabolomics studies has been completed on human topics, despite the fact that stepped forward diagnosis may additionally permit early interventions, alleviate disorder burden, and facilitate price-effective remedies.

It is envisioned that $60-70$ percentage of people with T2D have a few form of cardiac dysfunction or cardiovascular sickness. as a result, people with T2D are twice as probable as healthful controls to have heart disease or stroke, making cardiovascular ailment (CVD) the number one difficulty of diabetes [62]. nevertheless, CVD threat is often poorly managed in T2D sufferers [63].

wu et al. [64] used metabolomics to analyze particular cardiovascular risk elements which includes excessive blood strain, nonalcoholic fatty liver disease, and coronary heart sickness in a collection of T2D patients. their purpose became to discover biomarkers indicating one or more of these T2D co morbidities. regrettably, this look at most effective analyzed metabolic variations between those three danger elements and mixtures thereof and did not encompass a control group without CVD chance factors. even though the examine ought to show great metabolic 
variations between these sicknesses and their mixtures, the authors kingdom that the price of the outcomes is restrained as they were not able to recruit a matching manage group without T2D complications. Likewise, some other have a look at failed to predict coronary artery disorder in a hundred ninety T2D sufferers inside four years of comply with-up [65].

\section{Conclusions and future directions}

Within the post genomic generation, biologists and translational investigators alike have received a new appreciation for metabolic evaluation as a critical device for assessing the physiological and path physiological impact of genetic version. the contemporary surge in techniques development within the field of metabolomics is constructed on the muse of a long time of analytical biochemistry and its use in detecting inborn mistakes of metabolism. the predominant distinction among then and now is that the current emphasis is on techniques that permit simultaneous measurement of more than one analyses in a organic sample, whereas earlier work became regularly focused on one or a small variety of metabolites in line with assay. in spite of substantial advances, no unmarried profiling approach presently allows simultaneous evaluation of all of the metabolites inside the metabolome. Closing success of this aim would require endured in depth improvement of deeper libraries of chemical standards, instrument systems with extensive sensitivity variety and high mass accuracy, and possibly integration of ms and NMR methods to gain fulanalyzete insurance. Those advances must be coupled with continued improvement of computational strategies for analysis of complex metabolomic datasets and their integration with similarly complex genomic, transcriptomic, and proteomic profiles. In the meantime, vast progress can be made with the presently to be had "targeted" technologies that permit profiling of key intermediates of lipid, carbohydrate, purine, pyrimidine, and protein metabolism. The examples supplied herein approximately clinical insights received with the aid of application of modern-day tools propose a broad horizon and provide sturdy encouragement for further technology improvement in this region. but, it is able to be obvious to the reader that, up to now, simplest a subset of the research stated in this text have long past beyond the outline of metabolic "signatures" that signify distinctive physiological, path physiological, or drug-handled states (records) to real use of the signatures to pose after which test new hypotheses (knowledge). The paramount project of the subsequent segment of metabolomics research is to higher harvest the information from large datasets to create knowledge about metabolic regulatory mechanisms, perhaps leading to better know-how of perturbations in chronic diseases and situations together with type 2 diabetes, weight problems, CVD, and cancer.

\section{References}

1) S. Smyth and A. Heron, "Diabetes and obesity: the twin epidemics," Nature Medicine, vol. 12, no. 1, pp. 75-80, 2006. View at Publisher · View at Google Scholar · View at Scopus

2) D. R. Whiting, L. Guariguata, C. Weil, and J. Shaw, "Idf diabetes atlas: global estimates of the prevalence of diabetes for 2011 and 2030," Diabetes Research and Clinical Practice, vol. 94, no. 3, pp. 311-321, 2011. View at $\underline{\text { Publisher }}$. View at Google Scholar . View at $\underline{\text { Scopus }}$

3) J. Lindström and J. Tuomilehto, "The diabetes risk score: a practical tool to predict type 2 diabetes risk," Diabetes Care, vol. 26, no. 3, pp. 725-731, 2003. View at Publisher - View at Google $\underline{\text { Scholar }}$ View at Scopus

4) A. P. Carson, K. Reynolds, V. A. Fonseca, and P. Muntner, "Comparison of $\mathrm{A} 1 \mathrm{C}$ and fasting glucose criteria to diagnose diabetes among U.S. adults," Diabetes Care, vol. 33, no. 1, pp. 95-97, 2010. View at Publisher . View at Google $\underline{\text { Scholar }}$. View at Scopus

5) X.-R. Pan, G.-W. Li, Y.-H. Hu et al., "Effects of diet and exercise in preventing NIDDM in people with impaired glucose tolerance: the Da Qing IGT and diabetes study," Diabetes Care, vol. 20, no. 4, pp. 537-544, 1997. View at Publisher - View at Google Scholar · View at Scopus

6) J. Tuomilehto, J. Lindström, J. G. Eriksson et al., "Prevention of type 2 diabetes mellitus by changes in lifestyle among subjects with impaired glucose tolerance," The New England Journal of Medicine, vol. 344, no. 18, pp. 1343-1350, 2001. View at Publisher - View at Google $\underline{\text { Scholar }}$ - View at Scopus

7) W. C. Knowler, E. Barrett-Connor, S. E. Fowler et al., "Reduction in the incidence of type 2 diabetes with lifestyle intervention or metformin," The New England Journal of Medicine, vol. 346, no. 6, 
pp. 393-403, 2002. View at Publisher · View at Google Scholar · View at Scopus

8) H. C. Gerstein, S. Yusuf, J. Bosch et al., "Effect of rosiglitazone on the frequency of diabetes in patients with impaired glucose tolerance or impaired fasting glucose: a randomised controlled trial," The Lancet, vol. 368, no. 9541, pp. 10961105, 2006. View at Publisher . View at Google $\underline{\text { Scholar }}$

9) S. M. Grundy, C. E. Barlow, S. W. Farrell, G. L. Vega, and W. L. Haskell, "Cardiorespiratory fitness and metabolic risk," American Journal of Cardiology, vol. 109, no. 7, pp. 988-993, 2012. View at Publisher View at Google $\underline{\text { Scholar }}$. View at Scopus

10) J. L. Rosenzweig, E. Ferrannini, S. M. Grundy et al., "Primary prevention of cardiovascular disease and type 2 diabetes in patients at metabolic risk: an endocrine society clinical practice guideline," The Journal of Clinical Endocrinology \& Metabolism, vol. 93, no. 10, pp. 3671-3689, 2008. View at Publisher View at Google $\underline{\text { Scholar }}$ View at Scopus

11) J. Liu, S. M. Grundy, W. Wang et al., "Ten-year risk of cardiovascular incidence related to diabetes, prediabetes, and the metabolic syndrome," The American Heart Journal, vol. 153, no. 4, pp. 552-558, 2007. View at $\underline{\text { Publisher }}$. View at Google Scholar $\underline{\text { View at }}$ $\underline{\text { Scopus }}$

12) S. B. Heymsfield, D. Thomas, A. Bosy-Westphal, W. Shen, C. M. Peterson, and M. J. Müller, "Evolving concepts on adjusting human resting energy expenditure measurements for body size," Obesity Reviews, vol. 13, no. 11, pp. 10011014, 2012. View at Publisher · View at Google $\underline{\text { Scholar }}$ V View at Scopus

13) M. J. Müller, M. Lagerpusch, J. Enderle, B. Schautz, M. Heller, and A. Bosy-Westphal, "Beyond the body mass index: tracking body composition in the pathogenesis of obesity and the metabolic syndrome," Obesity Reviews, vol. 13, no. 2, pp. 6-13, 2012. View at Publisher View at Google Scholar · View at Scopus

14) D. M. Mutch, M. R. Temanni, C. Henegar et al., "Adipose gene expression prior to weight loss can differentiate and weakly predict dietary responders," PLoS ONE, vol. 2, no. 12, Article ID e1344, 2007.View at Publisher · View at Google $\underline{\text { Scholar }}$ View at Scopus

15) H. U. Zacharias, J. Hochrein, M. S. Klein, C. Samol, P. Oefner, and W. Gronwald, "Current experimental, bioinformatic and statistical methods used in NMR based metabolomics," Current Metabolomics, vol. 1, no. 3, pp. 253-268, 2013. View at Publisher · View at Google Scholar

16) J. C. Lindon and J. K. Nicholson, "Spectroscopic and statistical techniques for information recovery in metabonomics and metabolomics," Annual Review of Analytical Chemistry, vol. 1, no. 1, pp. 45-69, 2008. View at Publisher View at Google $\underline{\text { Scholar }} \cdot \underline{\text { View at Scopus }}$

17) R. Ramautar, G. W. Somsen, and G. J. de Jong, "CE-MS for metabolomics: developments and applications in the period 2010 2012," Electrophoresis, vol. 34, no. 1, pp. 86-98, 2013. View at Publisher View at Google $\underline{\text { Scholar }}$ View at Scopus

18) K. Kubota, T. Fukushima, R. Yuji et al., "Development of an HPLC-fluorescence determination method for carboxylic acids related to the tricarboxylic acid cycle as a metabolome tool," Biomedical Chromatography, vol. 19, no. 10, pp. 788-795, 2005. View at Publisher - View at Google Scholar . View at Scopus

19) W. Gronwald, M. S. Klein, H. Kaspar et al., "Urinary metabolite quantification employing 2D NMR spectroscopy," Analytical Chemistry, vol. 80, no. 23, pp. 9288-9297, 2008. View at $\underline{\text { Publisher }}$. View at Google Scholar . View at Scopus

20) M. S. Klein, P. J. Oefner, and W. Gronwald, "Metaboquant: a tool combining individual peak calibration and outlier detection for accurate metabolite quantification in $1 \mathrm{~d} 1 \mathrm{~h}$ and $1 \mathrm{~h}-13 \mathrm{c}$ hsqc NMR spectra," BioTechniques, vol. 54, no. 5, pp. 251-256, 2013. View at Google $\underline{\text { Scholar }} \cdot \underline{\text { View at Scopus }}$

21) M. S. Klein, K. E. Connors, J. Shearer, H. J. Vogel, and D. S. Hittel, "Metabolomics reveals the sex-specific effects of the sort1 low-density lipoprotein cholesterol locus in healthy young adults," Journal of Proteome Research, vol. 13, no. 11, pp. 5063-5070, 2014. View at $\underline{\text { Publisher }}$. View at Google Scholar 
22) H. U. Zacharias, G. Schley, J. Hochrein et al., "Analysis of human urine reveals metabolic changes related to the development of acute kidney injury following cardiac surgery," Metabolomics, vol. 9, no. 3, pp. 697707, 2013. View at Publisher View at Google Scholar View at Scopus

23) A.-H. Zhang, H. Sun, G.-L. Yan, Y. Yuan, Y. Han, and X.-J. Wang, "Metabolomics study of type 2 diabetes using ultra-performance LCESI/quadrupole-TOF high-definition MS coupled with pattern recognition methods," Journal of Physiology and Biochemistry, vol. 70, no. 1, pp. 117-128, 2014. View at Publisher View at Google Scholar · View at Scopus

24) E. Trushina, T. Dutta, X.-M. T. Persson, M. M. Mielke, and R. C. Petersen, "Identification of altered metabolic pathways in plasma and CSF in mild cognitive impairment and Alzheimer's disease using metabolomics," PLoS ONE, vol. 8, no. 5, Article ID e63644, 2013. View at $\underline{\text { Publisher }}$. View at Google Scholar . View at $\underline{\text { Scopus }}$

25) D. O. Mook-Kanamori, M. M. E.-D. Selim, A. H. Takiddin, A. H. Takiddin et al., "1, 5anhydroglucitol in saliva is a noninvasive marker of short-term glycemic control," The Journal of Clinical Endocrinology \& Metabolism, vol. 99, no. 3, pp. E479-E483, 2014. View at Google Scholar

26) W. Römisch-Margl, C. Prehn, R. Bogumil, C. Röhring, K. Suhre, and J. Adamski, "Procedure for tissue sample preparation and metabolite extraction for high-throughput targeted metabolomics," Metabolomics, vol. 8, no. 1, pp. 133-142, 2012. View at Publisher - View at Google Scholar · View at Scopus

27) O. Beckonert, M. Coen, H. C. Keun et al., "Highresolution magic-angle-spinning NMR spectroscopy for metabolic profiling of intact tissues," Nature protocols, vol. 5, no. 6, pp. 10191032, 2010. View at Publisher - View at Google $\underline{\text { Scholar }}$. View at Scopus

28) H. M. de Feyter, G. F. Mason, G. I. Shulman, D. L. Rothman, and K. F. Petersen, "Increased brain lactate concentrations without increased lactate oxidation during hypoglycemia in type 1 diabetic individuals," Diabetes, vol. 62, no. 9, pp. 30753080, 2013. View at Publisher - View at Google Scholar $\cdot$ View at Scopus
29) M. Wallace, H. Whelan, and L. Brennan, "Metabolomic analysis of pancreatic beta cells following exposure to high glucose," Biochimica et Biophysica Acta, vol. 1830, no. 3, pp. 25832590, 2013. View at Publisher View at Google $\underline{\text { Scholar }}$. View at Scopus

30) Z. Yu, G. Kastenmüller, Y. He et al., "Differences between human plasma and serum metabolite profiles," PLoS ONE, vol. 6, no. 7, Article ID e21230, 2011. View at Publisher · View at Google Scholar

31) D. G. A. J. Hebels, P. Georgiadis, H. C. Keun et al., "Performance in omics analyses of blood samples in long-term storage: opportunities for the exploitation of existing biobanks in environmental health research," Environmental Health Perspectives, vol. 121, no. 4, pp. 480-487, 2013. View at Publisher . View at Google $\underline{\text { Scholar }}$. View at Scopus

32) W. B. Dunn, D. Broadhurst, D. I. Ellis et al., "A GC-TOF-MS study of the stability of serum and urine metabolomes during the UK Biobank sample collection and preparation protocols," International Journal of Epidemiology, vol. 37, supplement 1, pp. i23-i30, 2008. View at Publisher View at Google Scholar . View at $\underline{\text { Scopus }}$

33) H. G. Gika, G. A. Theodoridis, and I. D. Wilson, "Liquid chromatography and ultra-performance liquid chromatography-mass spectrometry fingerprinting of human urine. Sample stability under different handling and storage conditions for metabonomics studies," Journal of Chromatography A, vol. 1189, no. 1-2, pp. 314322, 2008. View at Publisher - View at Google Scholar - View at Scopus

34) Napoli C, Sperandio N, Lawlor RT, Scarpa A, Molinari H, et al. (2011) Urine Metabolic Signature of Pancreatic Ductal Adenocarcinoma by $1 \mathrm{H}$ Nuclear

35) Magnetic Resonance: Identification, Mapping, and Evolution. J Proteome Res: Wu H, Volponi JV, Oliver AE, Parikh AN, Simmons BA, et al. (2011) In vivo lipidomics using single-cell Raman spectroscopy. Proc Natl Acad Sci 108: 3809-3814.

36) Krishna CM, Kurien J, Mathew S, Rao L, Maheedhar K, et al. (2008) Raman spectroscopy of breast tissues. Expert Rev Mol Diagn 8: 149166. 
37) Guo K, Peng J, Zhou R, Li L (2011) Ion-pairing reversed-phase liquid chromatography fractionation in combination with isotope labeling reversed-phase liquid chromatography-mass spectrometry for comprehensive metabolome profiling. J Chromatogr A 1218: 3689-3694.

38) Chen SP, Wu J, Yu XD, Xu JJ, Chen HY (2010) Multi-parameter detection of diabetes mellitus on multichannel poly (dimethylsiloxane) analytical chips coupled with nanoband microelectrode arrays. Electrophoresis 31: 3097-3106.

39) Hrydziuszko O, Silva MA, Perera MT, Richards DA, Murphy N, et al. (2010) Application of Metabolomics to Investigate the Process of Human Orthotopic Liver Transplantation: A Proof-of-Principle Study. OMICS 14: 143-150.

40) Zhang A, Sun H, Wang P, Han Y, Wang X (2012) Modern analytical techniques in metabolomics analysis. Analyst 137: 293-300.

41) Connor SC, Hansen MK, Corner A, Smith RF, Ryan TE (2010) Integration of metabolomics and transcriptomics data to aid biomarker discovery in type 2 diabetes. Mol BioSyst 6: 909-921.

42) Connor SC, Wu W, Sweatman BC, Manini J, Haselden JN, et al. (2004) Effects of feeding and body weight loss on the 1H-NMR-based urine metabolic profiles of male Wistar Han rats: implications for biomarker discovery. Biomarkers 9: 156-79.

43) Griffin JL, Williams HJ, Sang E, Nicholson JK (2001) Abnormal lipid profile of dystrophic cardiac tissue as demonstrated by one- and twodimensional magic-angle spinning $1 \mathrm{H}$ NMR spectroscopy. Magn Reson Med 46: 249-255.

44) Katajamaa M, Miettinen J, Orešič M (2006) MZmine: toolbox for processing and visualization of mass spectrometry based molecular profile data. Bioinformatics 22: 634-636.

45) Baran R, Kochi H, Saito N, Suematsu M, Soga T, et al. (2006) MathDAMP: a package for differential analysis of metabolite profiles. BMC Bioinformatics 7: 530.

46) Goodacre R, Vaidyanathan S, Dunn WB, Harrigan GG, Kell DB (2004) Metabolomics by numbers: acquiring and understanding global metabolite data. Trends Biotechnol 22: 245-252.
47) Kuhl C, Tautenhahn R, Böttcher C, Larson TR, Neumann S (2011) CAMERA:

An Integrated Strategy for Compound Spectra Extraction and Annotation of Liquid Chromatography/Mass Spectrometry Data Sets. Anal Chem.

48) Schripsema J (2010) Application of NMR in plant metabolomics: techniques, problems and prospects. Phytochem Anal 21: 14-21.

49) Lapolla A, Fedele D, Traldi P (2011) Diabetes and mass spectrometry. Diabetes Metab Res Rev 17: 99-112.

50) Wang C, Kong H, Guan Y, Yang J, Gu J, et al. (2005) Plasma phospholipid metabolic profiling and biomarkers of type 2 diabetes mellitus based on high-performance liquid chromatography/electro spray mass spectrometry and multivariate statistical analysis. Anal Chem 77: 4108- 4116.

51) Xia JF, Liang QL, Liang XP, Wang YM, Hu P, et al. (2009) Ultraviolet and tandem mass spectrometry for simultaneous quantification of 21 pivotal metabolites in plasma from patients with diabetic nephropathy. J Chromatogr B Analyt Technol Biomed Life Sci 877: 1930-1936.

52) Zhang J, Yan L, Chen W, Lin L, Song X, et al. (2009) Metabonomics research of diabetic nephropathy and type 2 diabetes mellitus based on UPLC-oaTOF-MS system. Anal Chim Acta 650: 16-22.

53) Verrijn Stuart AA, Schipper HS, Tasdelen I, Egan DA, Prakken BJ, et al. (2011) Altered Plasma Adipokine Levels and in Vitro Adipocyte Differentiation in Pediatric Type 1 Diabetes. J Clin Endocrinol Metab.

54) Dettmer K, Aronov PA, Hammock BD (2007) Mass spectrometry-based metabolomics. Mass Spectrom Rev 26: 51-78.

55) Dunn WB, Broadhurst D, Brown M, Baker PN, Redman CW, et al (2008) Metabolic profiling of serum using Ultra Performance Liquid Chromatography and the LTQ-Orbitrap mass spectrometry system. J Chromatogr B Analyt Technol Biomed Life Sci 871: 288-298.

56) Krone N, Hughes BA, Lavery GG, Stewart PM, Arlt W, et al. (2010) Gas chromatography/mass spectrometry (GC/MS) remains a pre-eminent discovery tool in clinical steroid investigations 
even in the era of fast liquid chromatography tandem mass spectrometry (LC/MS/MS). J Steroid Biochem Mol Biol 121: 496-504.

57) Ng DP, Salim A, Liu Y, Zou L, Xu FG, et al. (2011) A metabolomic study of low estimated GFR in non-proteinuric type 2 diabetes mellitus. Diabetologia: 55: 499-508.

58) Arlt W, Biehl M, Taylor AE, Hahner S, Libé R, et al. (2011) Urine Steroid Metabolomics as a Biomarker tool for detecting malignancy in adrenal tumors. J Clin Endocrinol Metab 96: 3775-3784.

59) Menéndez-Carreño M, Varo N, Mugueta C, Restituto P, Ansorena D, et al. (2011) Correlation between serum content of the main COPs (cholesterol oxidation products) from autoxidation and cardiovascular risk factors. Nutr Hosp 26: 144-151.

60) Vivekanadan-Giri A, Wang JH, Byun J, Pennathur S (2008) Mass spectrometric quantification of amino acid oxidation products identifies oxidative mechanisms of diabetic end-organ damage. Rev Endocr Metab Disord 9: 275-287.

61) Tavafi M, Ahmadvand H, Tamjidipoor A, Delfan B, Khalatbari AR (2011) Satureja khozestanica essential oil ameliorates progression of diabetic nephropathy in uninephrectomized diabetic rats. Tissue Cell 43: 45-51.

62) Fan X, Sell DR, Zhang J, Nemet I, Theves M, et al. (2010) Anaerobic vs aerobic pathways of carbonyl and oxidant stress in human lens and skin during aging and in diabetes: A comparative analysis. Free Radic Biol Med 49: 847-856.

63) Koek MM, Muilwijk B, van Stee LL, Hankemeier $\mathrm{T}$ (2008) Higher mass loadability in comprehensive two-dimensional gas chromatography-mass spectrometry for improved analytical performance in metabolomics analysis. J Chromatogr A 1186: 420-429.
64) Pierce KM, Hoggard JC, Mohler RE, Synovec RE (2008) Recent advancements in comprehensive two-dimensional separations with chemometrics. J Chromatogr A 1184: 341-352.

65) John Heim (2010) Analyzing Small Molecule Metabolite Profiles of Diabetic and Nondiabetic Urine Samples Using GCXGC-TOF-MS and Statistical Software as a Data-Mining Strategy.

66) Huang $X$, Regnier FE (2007) Differential metabolomics using stable isotope labeling and two-dimensional gas chromatography with timeof-flight mass spectrometry. Anal Chem 80: $107-$ 114.

67) Allwood JW, Goodacre R (2010) An introduction to liquid chromatography-mass spectrometry instrumentation applied in plant metabolomic analyses. Phytochem Anal 21: 33-47.

68) Becker S, Kortz L, Helmschrodt C, Thiery J, Ceglarek U (2011) LC-MS-based metabolomics in the clinical laboratory. J Chromatogr B Analyt Technol Biomed Life Sci Oct 22 in press.

69) Tsutsui H, Maeda T, Toyo'oka T, Min JZ, Inagaki $S$, et al. (2010) Practical analytical approach for the identification of biomarker candidates in prediabetic state based upon metabonomic study by ultraperformance liquid chromatography coupled to electro spray ionization time-of-flight mass spectrometry. J Proteome Res 9: 3912-3922.

70) Felig P, Marliss E, Cahill GF (1969) Plasma amino acid levels and insulin secretion in obesity. N Engl J Med 281: 811-816.

71) Newgard CB, An J, Bain JR, Muehlbauer MJ, Stevens RD, et al. (2009) A branched-chain amino acid-related metabolic signature that differentiates obese and lean humans and contributes to insulin resistance. Cell Metab 9: 311-326.

72) Ramautar R, Somsen GW, de Jong GJ (2009) CEMS in metabolomics. Electrophoresis 30: 276291. 